\title{
Soil Bedding Treatments Improve Pepper Plant Anchorage
}

\author{
Michael D. McCullough ${ }^{1}$, James E. Motes ${ }^{2}$, and Brian A. Kahn ${ }^{3}$ \\ Department of Horticulture and Landscape Architecture, Oklahoma State \\ University, Stillwater, OK 74078-0511
}

\author{
Additional index words. Capsicum annuum, lodging, mechanical harvest, $\mathrm{N}$ fertilization, \\ uprooting
}

\begin{abstract}
Two problems associated with machine harvesting of peppers (Capsicum annuum L.) are plant lodging during growth and uprooting. Factorial combinations of four bedding treatments and two $\mathrm{N}$ rates were compared for effects on lodging, uprooting, and fruit yield of chile and paprika-type peppers in Fort Cobb and Bixby, Okla. Bedding treatments were 1) no bed (T1); 2) no bed with $5 \mathrm{~cm}$ of soil hilled to the plant bases (T2); 3) bedded preplant, but bed not sustained (i.e., allowed to erode) during the growing season (T3); and 4) bedded preplant and bed sustained during the growing season (T4). All plots received preplant $N$ at $45 \mathrm{~kg} \cdot \mathrm{ha}^{-1}$. In 1992, one-half of the plots were sidedressed with 45 $\mathrm{kg} \mathrm{N} / \mathrm{ha}$. In 1993, one-half of the plots were sidedressed with $\mathrm{N}$ at 45 and $90 \mathrm{~kg}^{-h^{-1}}$ for paprika and chile, respectively. The higher $\mathrm{N}$ rates consistently produced larger and higher-yielding chile plants and generally increased yield and stem and leaf weights of paprika plants. The force required to uproot plants was not significantly affected by $\mathbf{N}$ rates. Plant lodging was significantly worse at the higher $\mathrm{N}$ rates in only one of five studies. Bedding treatments did not have a consistent influence on fruit yield. The force required to uproot plants was greater with $\mathrm{T} 2$ and 4 compared to $\mathrm{T} 1$ and 3 in three of four studies. Plant lodging was not influenced by the bedding treatments.
\end{abstract}

To our knowledge, no information is available on the influence of soil bedding and $\mathrm{N}$ rate on pepper plant anchorage and lodging. Peppers usually are hand-harvested, but mechanical harvesting is considered essential to expand production of processing peppers (Bender, 1993; Palevitch, 1978). Stripper mechanical harvesters require plants that are well anchored because uprooted plants may clog the harvester mechanism (Marshall, 1984). Lodged plants also can affect harvester performance adversely by disrupting the uniform flow of pepper plants into the harvester. Kahn (1985) described lodging as when the plant is sufficiently prostrate to place its fruit below the harvester level. There are three types of lodging: branch, stem, and root lodging (Johnson et al., 1973; Pinthus, 1973). Root and

Received for publication 17 Apr. 1995. Accepted for publication 17 June 1995. Approved for publication by the Director of the Oklahoma Agricultural Expt. Station. This research was supported under project H-1441 with additional support from the Oklahoma Center for Applied Science and Technology Grant ARO-087. The information given in this publication is for educational purposes only. Mention of a trademark, proprietary product, or vendor does not constitute a guarantee or warranty of the product nor does it imply approval or disapproval to the exclusion of other products or vendors that also may be suitable. The cost of publishing this paper was defrayed in part by the payment of page charges. Under postal regulations, this paper therefore must be hereby marked advertisement solely to indicate this fact.

${ }^{1}$ Former Graduate Assistant.

${ }^{2}$ Professor, to whom reprint requests should be addressed.

${ }^{3}$ Professor. branch lodging are most likely to occur in a pepper field. Root lodging occurs when straight and intact stems lean from the ground level due to a weakening in the root system (Pinthus, 1967). Branch lodging occurs when a branch is loaded with fruit and bends to the ground or, in severe cases, breaks (Johnson et al., 1973).

Wolf and Alper (1984) stated that efficient mechanical harvesting of peppers requires establishing complementary horticultural practices. One such practice is using beds and soil hilled to the base of the plants. Hilling soil to the base of the plants provides structural support and increases anchorage, which helps to reduce plant uprooting during mechanical harvesting (Marshall, 1984). Hilling must be practiced carefully because imprecise cultivation can increase lodging due to root damage (Stoffella and Kahn, 1986). Banks (1992) reported that deep cultivation of cotton (Gossypium hirsutum L.) reduced yield due to root pruning.

Nitrogen rates for pepper vary depending on production area and what pepper types and cultivars are grown. Rates can vary from 56 to $336 \mathrm{~kg} \mathrm{~N} / \mathrm{ha}$ in 'Anaheim Chili' grown in California (Payero et al., 1990). Sundstrom et al. (1984) reported that $112 \mathrm{~kg} \mathrm{~N} /$ ha was most desirable for Tabasco peppers (Capsicum frutescens L.). Stroehlein and Oebker (1979) suggested that chile yields were highest when $\mathrm{N}$ rates were between 100 and $150 \mathrm{~kg} \cdot \mathrm{ha}^{-1}$. Hartz et al. (1993) reported that yield and mean fruit size of drip-irrigated bell pepper in California peaked at 168 to $252 \mathrm{~kg} \mathrm{~N} / \mathrm{ha}$.

Nitrogen rates also play a part in determining plant size. Plant size is important when mechanical harvesting is being considered. Marshall (1984) reported that an upright plant with narrow crotch angles is optimal for me- chanical harvesting. Sundstrom et al. (1984) showed that high $\mathrm{N}$ rates and increased plant densities produced a plant structure that was favorable for machine harvest.

Our objective was to evaluate lodging, uprooting force, and yield when chile and paprika peppers were grown under four bedding practices and two $\mathrm{N}$ rates.

\section{Materials and Methods}

Field experiments were conducted in 1992 at the Caddo Research Station, Fort Cobb, Okla., and the Vegetable Research Station, Bixby, Okla. In 1993, the research was repeated in Bixby. In 1992, the Cobb fine sandy loam (fine-loamy, mixed, thermic, Udic Haplustalf) in Fort Cobb was fertilized with a broadcast, preplant-incorporated application of $45 \mathrm{~N}-50 \mathrm{P}-0 \mathrm{~K}\left(\mathrm{~kg} \cdot \mathrm{ha}^{-1}\right)$ based on soil test results. In 1992 and 1993, the Severn very fine sandy loam [coarse-silty, mixed (calcareous), thermic Typic Udifluvent] in Bixby was fertilized with a broadcast, preplant-incorporated application of $45 \mathrm{~N}-22 \mathrm{P}-41 \mathrm{~K}\left(\mathrm{~kg} \cdot \mathrm{ha}^{-1}\right)$. The preplant $\mathrm{N}$ represented a low rate of $45 \mathrm{~kg} \cdot \mathrm{ha}^{-1}$ applied to all plots in 1992 and 1993. At the onset of fruiting in 1992, one-half of the plots received a sidedressing with $\mathrm{N}$ at $45 \mathrm{~kg} \cdot \mathrm{ha}^{-1}$. The combination of preplant and sidedressed $\mathrm{N}$ represented the higher $\mathrm{N}$ rate. In 1993, we increased the sidedressed $\mathrm{N}$ rate from 45 to 90 $\mathrm{kg} \cdot \mathrm{ha}^{-1}$ on the chile plots to test the hypothesis that the optimum $\mathrm{N}$ rate had not been reached yet. Dates of sidedress N fertilization in 1992 were 29 June in Bixby and 1 July in Fort Cobb. In 1993, chile were sidedressed twice (on 16 July and 27 Aug.) and paprika once (on 16 July) with $45 \mathrm{~kg} \cdot \mathrm{ha}^{-1}$ per application each time. The source of $\mathrm{N}$ in all the sidedressings was $\mathrm{NH}_{4} \mathrm{NO}_{3}(34 \mathrm{~N}-0 \mathrm{P}-0 \mathrm{~K})$.

The advanced breeding lines Oklahoma Chile and Paprika 50 were direct-field-seeded. The chile seeding rate was $1.7 \mathrm{~kg} \cdot \mathrm{ha}^{-1}$ at both sites in 1992 and $2.1 \mathrm{~kg} \cdot \mathrm{ha}^{-1}$ in 1993. Paprika seeding rate was 5.6 and $3.2 \mathrm{~kg} \cdot \mathrm{ha}^{-1}$ in 1992 and 1993, respectively. In 1992, planting dates were 9 Apr. in Fort Cobb and 10 Apr. in Bixby. Replanting was necessary in 1993 due to poor emergence resulting from excessive rainfall and soil crusting. The first seeding date was on 12 Apr.; reseeding was on 17 May. Plants were hand-thinned to the desired density of one plant every 7.5 to $10 \mathrm{~cm}$ within the row. In 1992, thinning in Bixby was on 27 May and 4 June in Fort Cobb; in 1993, in Bixby it was on 23 June.

In 1992, weeds were controlled with a preplant $N, N$-diethyl-2-(1-naphthaleneyloxy)propionamide (napropamide) application at $1.7 \mathrm{~kg} \cdot \mathrm{ha}^{-1}$ in both locations. In 1993, in Bixby, napropamide was applied at $1.9 \mathrm{~kg} \cdot \mathrm{ha}^{-1}$ on 12 Apr. An additional application of napropamide was made after replanting on 17 May at 1.1 $\mathrm{kg} \cdot \mathrm{ha}^{-1}$. Plots were kept weed free by mechanical and hand cultivation. Sprinkler irrigation was provided to supplement rainfall based on a subjective evaluation of soil moisture and crop observations.

The bedding treatments were 1) no bed (T1);2) no bed with $5 \mathrm{~cm}$ of soil hilled to the 
base of plants (T2); 3) bedded preplant with 10 -cm-high and $35-\mathrm{cm}$-wide flat top beds, but bed not sustained (allowed to erode) during the growing season (T3); and 4) bedded preplant and sustained (bed erosion repaired) during the growing season (T4). T2 and 4 were repaired on 14 July in Bixby and 20 July 1992 in Fort Cobb. The bedding treatments needed to be sustained twice in 1993 (30 Aug. and 24 Sept.) due to greater than normal rainfall, which eroded the beds and washed away hilled soil.

Harvest was after frost each year to simulate grower practice. Harvest dates in 1992 were 6 Nov. in Fort Cobb, and 30 Nov. in Bixby. Harvest was on 3 Nov. 1993 in Bixby. Plants were measured and observations were recorded before harvest. Plant height and width were measured on three representative plants in the data collection rows, and the average value for each plot was recorded. The total number of plants and the number of lodged plants in $3 \mathrm{~m}$ of data collection row were counted. Five plants were chosen at random to measure uprooting force with a wire cablepuller, spring scale, and a lever based on a fulcrum (Cooksey et al., 1994). The aboveground plant material in $3 \mathrm{~m}$ of row was cut off at soil level, placed in burlap bags, and dried at 48C for 1 week. Data collected after drying included stem diameter of 10 plants, total weight of plant matter, and fruit weight.

A $2 \times 4$ factorial arrangement of treatments was used in a split-plot design arranged in randomized blocks with six replications. The main plots were $\mathrm{N}$ rates and the subplots were bedding treatments. A plot consisted of four rows, with the two middle rows used for data collection. Plot length was $6.0 \mathrm{~m}$ in Bixby and $8.5 \mathrm{~m}$ in Fort Cobb. Between-row spacing was $0.9 \mathrm{~m}$. Data were evaluated by analysis of variance and general linear model procedures (SAS Institute, 1982).

\section{Results and Discussion}

No significant interactions were found between the $\mathrm{N}$ rates and bedding treatments for any of the variables analyzed in the five stud- ies. Plant stand at harvest was not significantly different for bedding treatments or $\mathrm{N}$ rates within a given experiment (data not presented).

Plants were taller at the higher $\mathrm{N}$ rates in chile but not in paprika (Table 1). Plants were wider at the higher $\mathrm{N}$ rates in all studies, except for paprika in 1992. The higher $\mathrm{N}$ rates increased lodging in only one of the three studies with chile, and it never significantly influenced paprika lodging. Stems were thicker in paprika with the higher $\mathrm{N}$ rates but not in chile. Uprooting force was not significantly affected by $\mathrm{N}$ rate in any of the studies. In 1992 , uprooting force in chile was $>450 \mathrm{~N}$ due to dry soil conditions at harvest in Fort Cobb, and actual values could not be determined with available equipment. Fruit dry weights were higher with the higher $\mathrm{N}$ rates in all studies, except with paprika in 1993. Stem and leaf dry weights were higher with the higher $\mathrm{N}$ rates in all studies (Table 1).

Plant height and width were not significantly influenced by the bedding treatments, except for chile plant width in Bixby in 1993, where bedding (T3 and 4) produced wider plants than planting without beds (T1 and 2) (Table 2). This difference might have resulted from the late replanting date in 1993. The beds may have provided a more favorable environment for early root growth, as reported by Banks (1992), which in turn promoted more top growth. Bedding treatments did not affect lodging. In 1992, chile stems were thicker in $\mathrm{T} 3$ and 4 in Bixby, when contrasted with T1 and 2 . There were no other significant effects of bedding treatments on stem diameter (Table 2).

More force was required to uproot plants with hills and sustained bedding (T2 and 4) compared to plants in the flat and nonsustained beds ( $\mathrm{T} 1$ and 3 ) in three of four studies where uprooting force was determined (Table 2). In 1993, paprika plants on beds (T3 and 4) also required more force to uproot than nonbedded plants (T1 and 2). The greater uprooting force needed for plants in the hilled and sustained treatments indicates better anchorage, possibly due to bigger roots, as suggested by Stoffella and Kahn (1986). The extra soil around the bases of hilled and sustained plants also provides structural support, which would further reduce plant uprooting problems during mechanical harvesting (Marshall, 1984).

In 1992, chile plants in Bixby had greater fruit dry weight in flat-ground plots (T1 and 3) when contrasted with hilled nonsustained plots (T2 and 4) (Table 2). In 1992, paprika plants in Bixby had higher fruit dry weight when not bedded (T1 and 2) than when bedded (T3 and 4). There were no significant differences in fruit dry weight due to the bedding treatments in the other three studies. Bedding did not produce significant effects on stem and leaf dry weights, except for paprika in Bixby in 1992 (Table 2). Root systems may have been damaged during the sustaining of T2 and 4 during the 1992 growing season. There was some visible damage to chile plant roots during this operation. According to Miller(1986), any stress originating in the roots affects the rest of the plant and can reduce yield. The root system and the fruit act as competing sinks for carbohydrates (Miller, 1986). Once stress occurs to the roots, the plant assimilates are redirected from the fruit to the roots to rebuild the damaged area, thereby reducing fruit yields.

The higher $\mathrm{N}$ rates consistently produced larger and higher yielding chile plants and generally increased yield and stem and leaf dry weights of paprika plants. The higher $\mathrm{N}$ rates tended to increase lodging, but differences were significant only in one of five studies. Plant uprooting forces also were not significantly affected by $\mathrm{N}$ rates. Further research is needed, but based on our studies, $\mathrm{N}$ rates of $135 \mathrm{~kg} \cdot \mathrm{ha}^{-1}$ for chile and $90 \mathrm{~kg} \cdot \mathrm{ha}^{-1}$ for paprika appear to be better than $45 \mathrm{~kg} \cdot \mathrm{ha}^{-1}$. This recommendation generally agrees with findings of Stroehlein and Oebker (1979) and Sundstrom et al. (1984).

The bedding treatments did not have a consistent influence on fruit yield in our studies; however, in three of four, more force was required to uproot plants when peppers were planted without beds and hilled or when planted on beds that were sustained compared to when they were planted on the flat or on beds that were not sustained. Uprooting of plants is not

Table 1. Effects of two $\mathrm{N}$ rates on plant characteristics and yield of chile and paprika-type peppers.

\begin{tabular}{|c|c|c|c|c|c|c|c|c|c|c|c|c|c|c|}
\hline \multirow{3}{*}{$\begin{array}{l}\mathrm{N} \\
\text { rate } \\
\left(\mathrm{kg} \cdot \mathrm{ha}^{-1}\right)\end{array}$} & \multicolumn{4}{|c|}{ Plant } & \multirow{2}{*}{\multicolumn{2}{|c|}{$\begin{array}{l}\text { Lodged } \\
\text { plants } \\
\left(\text { no. } / \mathrm{m}^{2}\right)\end{array}$}} & \multirow{2}{*}{\multicolumn{2}{|c|}{$\begin{array}{l}\text { Stem } \\
\text { diam. } \\
(\mathrm{mm})\end{array}$}} & \multirow{2}{*}{\multicolumn{2}{|c|}{$\begin{array}{l}\text { Plant } \\
\text { uprooting } \\
\text { force } \\
(\mathrm{N}) \\
\end{array}$}} & \multirow{2}{*}{\multicolumn{2}{|c|}{$\begin{array}{c}\text { Fruit } \\
\text { dry wt } \\
\left(\mathrm{Mg} \cdot \mathrm{ha}^{-1}\right)\end{array}$}} & \multirow{2}{*}{\multicolumn{2}{|c|}{$\begin{array}{c}\text { Stem } \\
\text { and leaf } \\
\text { dry wt } \\
\left(\mathrm{Mg} \cdot \mathrm{ha}^{-1}\right)\end{array}$}} \\
\hline & \multicolumn{2}{|c|}{$\begin{array}{c}\mathrm{Ht} \\
(\mathrm{cm})\end{array}$} & \multicolumn{2}{|c|}{$\begin{array}{l}\text { Width } \\
(\mathrm{cm})\end{array}$} & & & & & & & & & & \\
\hline & Chile & Paprika & Chile & Paprika & Chile & Paprika & Chile & Paprika & Chile & Paprika & Chile & Paprika & Chile & Paprika \\
\hline \multicolumn{15}{|c|}{ Fort Cobb, 1992} \\
\hline 45 & 42 & & 46 & & 0.4 & & 9.7 & & $--^{z}$ & & 2.53 & & 2.23 & \\
\hline 90 & 50 & & 52 & & 0.7 & & 10.1 & & --- & & 3.39 & & 3.04 & \\
\hline Significance & $* *$ & & $* *$ & & $*$ & & NS & & --- & & $* *$ & & $* *$ & \\
\hline \multicolumn{15}{|c|}{ Bixby, 1992} \\
\hline 45 & 53 & 64 & 45 & 48 & 0.0 & 1.5 & 11.2 & 8.9 & 294 & 157 & 2.26 & 1.20 & 2.65 & 1.76 \\
\hline 90 & 58 & 68 & 48 & 51 & 0.0 & 1.9 & 11.7 & 9.4 & 304 & 167 & 2.86 & 1.51 & 3.20 & 2.21 \\
\hline Significance & $* *$ & NS & $* *$ & NS & NS & NS & NS & $*$ & NS & NS & $* *$ & $* *$ & $* *$ & $* *$ \\
\hline \multicolumn{15}{|c|}{ Bixby, 1993} \\
\hline 45 & 55 & 53 & 46 & 41 & 0.0 & 1.5 & 9.1 & 7.8 & 294 & 186 & 1.86 & 0.53 & 2.62 & 1.24 \\
\hline 90 & -- & 58 & --- & 47 & --- & 1.9 & -- & 8.7 & -- & 186 & --- & 0.67 & --- & 1.64 \\
\hline 135 & 63 & --- & 52 & --- & 0.4 & --- & 9.8 & --- & 294 & --- & 2.15 & --- & 4.00 & --- \\
\hline Significance & $* *$ & NS & $* *$ & $*$ & NS & NS & NS & $*$ & NS & NS & $* *$ & NS & $* *$ & $*$ \\
\hline
\end{tabular}

${ }^{2}$ Uprooting force values not determined at Fort Cobb in 1992.

ns, , *** Nonsignificant or significant at $P \leq 0.05$ or 0.01 , respectively. 


\begin{tabular}{|c|c|c|c|c|c|c|c|c|c|c|c|c|c|c|}
\hline \multirow{3}{*}{$\begin{array}{l}\text { Soil } \\
\text { bedding } \\
\text { treatments }^{\mathrm{z}}\end{array}$} & \multicolumn{4}{|c|}{ Plant } & \multirow{2}{*}{\multicolumn{2}{|c|}{$\begin{array}{c}\text { Lodged } \\
\text { plants } \\
\left(\text { no. } / \mathrm{m}^{2}\right)\end{array}$}} & \multirow{2}{*}{\multicolumn{2}{|c|}{$\begin{array}{l}\text { Stem } \\
\text { diam. } \\
(\mathrm{mm})\end{array}$}} & \multirow{2}{*}{\multicolumn{2}{|c|}{$\begin{array}{l}\text { Plant } \\
\text { uprooting } \\
\text { force } \\
(\mathrm{N})\end{array}$}} & \multirow{2}{*}{\multicolumn{2}{|c|}{$\begin{array}{c}\text { Fruit } \\
\text { dry wt } \\
\left(\mathrm{Mg} \cdot \mathrm{ha}^{-1}\right)\end{array}$}} & \multirow{2}{*}{\multicolumn{2}{|c|}{$\begin{array}{c}\text { Stem } \\
\text { and leaf } \\
\text { dry wt } \\
\left(\mathrm{Mg} \cdot \mathrm{ha}^{-1}\right)\end{array}$}} \\
\hline & \multicolumn{2}{|c|}{$\begin{array}{l}\mathrm{Ht} \\
(\mathrm{cm})\end{array}$} & \multicolumn{2}{|c|}{$\begin{array}{l}\text { Width } \\
(\mathrm{cm})\end{array}$} & & & & & & & & & & \\
\hline & Chile & Paprika & Chile & Paprika & Chile & Paprika & Chile & Paprika & Chile & Paprika & Chile & Paprika & Chile & Paprika \\
\hline \multicolumn{15}{|c|}{ Fort Cobb, 1992} \\
\hline 1) $\mathrm{NB}$ & 48 & & 50 & & 0.7 & & 9.9 & & $---y$ & & 3.22 & & 2.73 & \\
\hline 2) $\mathrm{NBH}$ & 46 & & 50 & & 0.4 & & 9.6 & & --- & & 2.83 & & 2.64 & \\
\hline 3) $\mathrm{B}$ & 46 & & 47 & & 0.4 & & 10.5 & & --- & & 2.90 & & 2.74 & \\
\hline 4) $\mathrm{B}-\mathrm{S}$ & 45 & & 49 & & 0.4 & & 9.5 & & --- & & 2.88 & & 2.44 & \\
\hline \multicolumn{15}{|l|}{$\begin{array}{l}\text { Contrasts of } \\
\text { treatments }\end{array}$} \\
\hline 1,2 vs. 3,4 & NS & & NS & & NS & & NS & & --- & & NS & & NS & \\
\hline 2,4 vs. 1,3 & NS & & NS & & NS & & NS & & --- & & NS & & NS & \\
\hline \multicolumn{15}{|c|}{ Bixby, 1992} \\
\hline 1) $\mathrm{NB}$ & 57 & 66 & 46 & 51 & 0.0 & 1.5 & 11.5 & 9.0 & 294 & 147 & 2.84 & 1.54 & 3.07 & 2.03 \\
\hline 2) $\mathrm{NBH}$ & 55 & 67 & 46 & 50 & 0.0 & 1.5 & 10.7 & 9.0 & 294 & 167 & 2.46 & 1.46 & 2.88 & 2.11 \\
\hline 3) $\mathrm{B}$ & 55 & 64 & 48 & 48 & 0.0 & 1.5 & 12.3 & 9.4 & 284 & 147 & 2.58 & 1.23 & 2.88 & 1.91 \\
\hline 4) $\mathrm{B}-\mathrm{S}$ & 55 & 66 & 47 & 49 & 0.0 & 1.1 & 11.6 & 9.2 & 294 & 167 & 2.37 & 1.18 & 2.88 & 1.89 \\
\hline \multicolumn{15}{|l|}{$\begin{array}{r}\text { Contrasts of } \\
\text { treatments }\end{array}$} \\
\hline 1,2 vs. 3,4 & NS & NS & NS & NS & NS & NS & $*$ & NS & NS & NS & NS & $* *$ & NS & $*$ \\
\hline 2,4 vs. 1,3 & NS & NS & NS & NS & NS & NS & NS & NS & NS & $*$ & $* *$ & NS & NS & NS \\
\hline \multicolumn{15}{|c|}{ Bixby, 1993} \\
\hline 1) $\mathrm{NB}$ & 60 & 55 & 48 & 44 & 0.4 & 1.9 & 9.3 & 8.3 & 255 & 157 & 2.08 & 0.58 & 3.25 & 1.42 \\
\hline 2) $\mathrm{NBH}$ & 56 & 56 & 47 & 44 & 0.0 & 1.1 & 9.0 & 8.2 & 314 & 206 & 1.86 & 0.61 & 3.23 & 1.49 \\
\hline 3) $\mathrm{B}$ & 60 & 56 & 50 & 44 & 0.4 & 1.5 & 9.4 & 8.6 & 275 & 177 & 1.91 & 0.62 & 3.32 & 1.44 \\
\hline 4) $\mathrm{B}-\mathrm{S}$ & 59 & 55 & 52 & 44 & 0.4 & 1.9 & 9.9 & 7.9 & 324 & 226 & 2.17 & 0.59 & 3.43 & 1.40 \\
\hline \multicolumn{15}{|l|}{$\begin{array}{r}\text { Contrasts of } \\
\text { treatments }\end{array}$} \\
\hline 1,2 vs. 3,4 & NS & NS & $* *$ & NS & NS & NS & NS & NS & NS & $*$ & NS & NS & NS & NS \\
\hline 2,4 vs. 1,3 & NS & NS & NS & NS & NS & NS & NS & NS & $* *$ & $* *$ & NS & NS & NS & NS \\
\hline
\end{tabular}

${ }^{\mathrm{z}} \mathrm{NB}=$ no bed; $\mathrm{NBH}=$ no bed, hilled; $\mathrm{B}$ = bedded; $\mathrm{B}-\mathrm{S}$ = bedded-sustained.

y Uprooting force values not determined at Fort Cobb in 1992.

Ns, *, ** Nonsignificant or significant at $P \leq 0.05$ or 0.01 , respectively.

a current problem for Oklahoma chile growers when harvesting by machine because entire plants are cut off near the soil level and taken into the machine. There is grower interest in a stripper harvest system, which is currently used for harvesting paprika peppers in Oklahoma. The stripper system is faster than harvesting the entire plant, but requires stronger plant anchorage (Marshall, 1984). Because soil bedding treatments improved plant anchorage, planting without beds and hilling, or planting on beds and sustaining the beds, are the recommended methods for chile and paprika production on the soils in this study.

\section{Literature Cited}

Banks, J.C. 1992. Tillage management in cotton, p. 17-20. In: J.C. Banks, L.M. Verhalen, G.W. Cuperus, and M.A. Karner (ed.). Cotton production and pest management in Oklahoma. Oklahoma Coop. Ext. Serv. Circ. E-883.

Bender, D.A. 1993. Pepper production and harvesting research for the High Plains. In: B. Villalon (ed.). Proc. 9th Biennial Texas Pepper Conf., Weslaco, Texas.
Cooksey, J.R., B.A. Kahn, and J.E. Motes. 1994. Plant morphology and yield of paprika pepper in response to method of stand establishment. HortScience 29:1282-1284.

Hartz, T.M., M. LeStrange, and D.M. May. 1993. Nitrogen requirements of drip-irrigated peppers. HortScience 28:1097-1099.

Johnson, W.A., C.E. Evans, M.H. Hollingsworth, and E.L. Mayton. 1973. Production practices for Pimiento pepper-Fertilizer rates, plant spacings, and varietal strains. Auburn Univ. Agr. Expt. Sta. Bul. 444.

Kahn, B.A. 1985. Characterization of lodging differences in paprika pepper. HortScience 20:207209.

Marshall, D.E. 1984. Horticultural requirements for mechanical pepper harvesting, p. 389-396. In: Amer. Soc. Agr. Eng. Proc. Intl. Symp. on Fruit, Nut, and Vegetable Harvesting Mechanization, Bet Dagan, Israel, 5-12 Oct. 1983. ASAE Publ. 5-84.

Miller, D.E. 1986. Root systems in relation to stress tolerance. HortScience 21:963-970.

Palevitch, D. 1978. Cultural practices and cultivars for once-over harvested sweet paprika. Acta Hort. 73:255-262.

Payero, J.O., M.S. Bhangoo, and J.J. Steiner. 1990.
Nitrogen fertilizer management practices to enhance seed production by 'Anaheim Chili' peppers. J. Amer. Soc. Hort. Sci. 115:245-251.

Pinthus, M.J. 1967. Spread of the root system as indicator for evaluating lodging resistance of wheat. Crop Sci. 7:107-110.

Pinthus, M.J. 1973. Lodging in wheat, barley, and oats: The phenomenon, its causes and preventative measures. Adv. Agron. 25:209-263.

SAS Institute. 1982. SAS user's guide: Statistics. 1982 ed. SAS Inst., Cary, N.C.

Stoffella, P.J. and B.A. Kahn. 1986. Root system effects on lodging of vegetable crops. HortScience 21:960-963.

Stroehlein, J.L. and N.F. Oebker. 1979. Effects of nitrogen and phosphorus on yields and tissue analysis of chili peppers. Commun. Soil Sci. \& Plant Anal. 10:551-563.

Sundstrom, F., C. Thomas, R. Edwards, and G. Baskin. 1984. Influence of nitrogen and plant spacing on mechanically harvested Tabasco pepper. J. Amer. Soc. Hort. Sci. 109:642-645.

Wolf, I. and Y. Alper. 1984. Mechanization of paprika harvest, p. 265-275. In: Amer. Soc. Agr. Eng. Proc. Intl. Symp. on Fruit, Nut, and Vegetable Harvesting Mechanization, Bet Dagan, Israel, 5-12 Oct. 1983. ASAE Publ. 5-84. 